* Mestranda em Direito, com ênfase em filosofia do Direito, pela Universidade Federal do Paraná (2014), sob a orientação do prof. Dr. Celso Luiz Ludwig. Possui especialização em Direito do Estado (2009) e graduação em Direito (2003-2008), ambos pela Universidade Estadual de Londrina. E-mail: anapaula .ompaiva@gmail.com

** Doutora em Direito Constitucional, com ênfase em direitos humanos, pela Pontifícia Universidade Católica de São Paulo/BR (2010-2013). Mestre em Filosofia do Direito pela Pontifícia Universidade Católica de São Paulo/BR (2008). Possui aperfeiçoamento em Direitos Humanos pelo Institut International des Droits de L'homme (Strasbourg/FR, 2005) e graduação em Direito pela Universidade $\mathrm{Fe}$ deral do Paraná/BR (2005). E-mail: melinafachin@ gmail.com

\section{Democracia radical e acesso à justiça: repensando o espaço do político na jurisdição constitucional}

\author{
RADICAL CITIZENSHIP AND ACCESS TO JUSTICE: \\ RETHINKING THE POLITICAL AREA IN \\ CONSTITUTIONAL JURISDICTION
}

\author{
* Ana Paula de Oliveira Mazoni Vanzela Paiva \\ ** Melina Girardi Fachin
}

Resumo: O presente artigo deteve-se sobre a análise da cidadania radical, inspirada na vertente filosófica propugnada por Chantal Mouffe, como vetor de influência e transformação da inefetividade do acesso à justiça no ínterim da jurisdição constitucional. A partir de uma "revolução democrática" e pautando-se pelas noções de agonismo democrático, que encontra na figura do outro um adversário cuja existência é legítima e deve ser respeitada, manifesta-se a acepção utópica da democracia, em prol da negação de um espaço público unificado. Para tanto, a partir da necessidade de multiplicação dos espaços de participação e inclusão, e considerando o protagonismo da atuação judicial que deve empreender esforços para a consecução de direitos e garantias fundamentais, tem-se na jurisdição constitucional arena de luta pacífica de acesso em prol da reserva de justiça propugnada pelo Constituinte.

Palavras-chaves: Cidadania Radical; Agonismo democrático; Acesso à justiça; Jurisdição constitucional.

Abstract: This paper dedicated to the analysis of radical citizenship, inspired by the philosophical view encouraged by Chantal Mouffe, as a vector of influence and transformation of the ineffectiveness of the access to Justice focused on the constitutional court. From a "democratic revolution" and guided by notions of democratic agonism that finds out in the figure of the other an adversary whose existence is legit and must be respected, expresses the sense of a utopian democracy, towards denying a unified public space. Therefore, from the necessity of multiplication of spaces for participation and inclusion, and considering the protagonism of judicial action that should make efforts to enforce fundamental rights and guarantees, the constitutional jurisdiction arises as a peaceful struggle arena towards access the reservation of justice a backed by the Constituent Assembly.

Keywords: Radical Citizenship; Democratic agonism; Access to Justice; Constitutional jurisdiction. 


\section{INTRODUÇÃO}

A presente reflexão trata da análise acerca da cidadania radical como vetor de influência e transformação da (in)efetividade do direito fundamental ao acesso à justiça. Para tanto, objetiva o emprego dos ditames oriundos da teoria da democracia radical, que parte de uma "revolução democrática"1 como forma de repensar o espaço do político no ínterim das decisões políticas tomadas pela jurisdição constitucional e, assim, viabilizar o acesso à justiça.

Parte-se do pressuposto, inafastável, de que o Estado contemporâneo é um Estado de direitos fundamentais, ou seja, sua função instrumental se dirige à consolidação de tal gama de direitos. Como consequência desta consolidação, as expectativas sociais dos titulares destes direitos e garantias assolam a função judiciária, que assume papel de grande importância no cenário jurídico (nacional).

Neste cenário é imperioso que a própria noção de cidadania seja radicalmente democratizada, com vistas a possibilitar acesso à justiça efetivo, do ponto de vista de participação emancipatória, que legitima a jurisdição constitucional e concretiza a reserva de justiça ${ }^{2}$ propugnada pelo Constituinte.

Não obstante não se poder considerar a atividade política da função judiciária fenômeno recente ${ }^{3}$, se está a possibilitar evidente e forte atuação judicial na consecução de direitos e garantias fundamentais, tudo em prol da base que se serve a dignidade da pessoa humana.

A esse respeito, orienta CLÈVE (2012a, p. 25):

\footnotetext{
1 Termo firmado por Alexis de Tocqueville como significante da redução progressiva do distanciamento existente entre nobres e plebeus: "Uma grande revolução democrática se realiza em nós; todos a veem, mas nem todos a julgam da mesma maneira. Uns a consideram uma coisa nova e, tomando-a por um acidente, esperam ainda poder detê-la; enquanto outros a julgam irresistível, porque ela lhes parece o fato mais contínuo, mais antigo e mais permanente que se conhece na história" (TOCQUEVILlE, Alexis de. A democracia na América. São Paulo: Martins Fontes, 2001, p. 08).

2 Expressão cunhada por José Joaquim Gomes Canotilho (CANOTILHO, J. J. Gomes. Direito Constitucional. 5 ed. Coimbra: Livraria Almedina, 1992, p. 113 e seguintes).

3 Já que, nos dizeres de Ana Lúcia P. Pereira: "Já antes do positivismo normativista se reconhecia o exercício da atividade política pela jurisdição constitucional. A diferença é que, sob o direito prémoderno, a jurisprudência era fonte legítima de direito; sob o direito moderno, a fonte legítima era apenas a lei posta, mas, a discricionariedade judicial era reconhecida como inevitável quando insuficiente a disciplina legal; e, sob o direito contemporâneo, ao que antes de chamava discricionariedade judicial, pode-se nomear atividade política, frente a qual se tem buscado construir mecanismos direcionados à sua contençaõ”. (PEREIRA, Ana Lúcia Pretto. A atividade política da jurisdição constitucional brasileira: algumas dimensões. In: CLÈVE, Clèmerson Merlin (Coord.). Constituição, democracia e justiça: aportes para um constitucionalismo igualitário. Belo Horizonte: Fórum, 2011, p. 21).
} 
É preciso considerar, entretanto, que democracia não significa simplesmente governo da maioria. Afinal, a minoria de hoje poder ser a maioria de amanhã, e o guardião desta dinâmica majoritária/contra-majoritária, em última instância, que age como uma espécie de delegado do Poder Constituinte. Ou seja, a democracia não repele, ao contrário, reclama a atuação do Judiciário nesse campo.

A sociedade contemporânea é cenário de disputas complexas, discordância, pluralismos e dilemas políticos que necessitam da instrumentalização de maneiras de preservar o debate público e participação dos cidadãos nas decisões sociais de cunho significativo sem cercear o cunho democrático da deliberação. Ou seja, em meio a um emaranhado de opiniões e interesses conflitantes, o debate público deve ser garantido a fim de possibilitar a democracia concreta do ponto de vista radical, resguardando aos cidadãos o direito de interagir e influir nas decisões políticas de forma eficaz (e não apenas as elites políticas), ainda que e, sobretudo se, tomadas no ínterim do exercício da jurisdição constitucional ${ }^{4}$.

Se as ideias de cidadania e democracia são essenciais e inquestionáveis para a efetividade dos direitos fundamentais ${ }^{5}$, cumpre ressaltar que logra analisar a influência da vertente teórica da democracia radical na consecução desse mister, relacionando a participação cidadã, transmutada em acesso democrático

\footnotetext{
${ }^{4}$ Salienta-se que, sob hipótese alguma, busca-se universalizar o conceito de democracia ou torna-lo intocável. Pelo contrário, a partir do paradigma da revolução democrática tudo passa a ser condicionado e questionável, não obstante não se transmite em um relativismo já que "sempre deverá existir aquilo que se pode chamar de um conteúdo mínimo de moralidade". Para Chantal Mouffe: "De fato, nós devemos reconhecer que a democracia não exige uma teoria da verdade ou noções como incondicionalidade ou universalidade; o que se exige para a democracia é um conjunto de práticas e movimentos pragmáticos que objetivem convencer as pessoas a ampliar seu grau de comprometimento com os outros e construir uma sociedade mais inclusiva". (MOUFFE, Chantal. Teoria Política, direitos e democracia. In: FONSECA, Ricardo Marcelo (Org.). Repensando a Teoria do Estado. Belo Horizonte: Editora Fórum, 2004, p. 383).

${ }^{5}$ Imperioso que se reconheça que democracia e direitos fundamentais caminham juntos. Conforme preceitua Ingo Wolfgang Sarlet: "A imbricação dos direitos fundamentais com a ideia específica de democracia é outro aspecto que impende seja ressaltado. Com efeito, verifica-se que os direitos fundamentais podem ser considerados simultaneamente pressuposto, garantia e instrumento do princípio democrático da autodeterminação do povo por intermédio de cada indivíduo, mediante o reconhecimento do direito de igualdade (perante a lei e de oportunidades), de um espaço de liberdade real, bem como por meio da outorga do direito à participação (com liberdade e igualdade), na conformação da comunidade e do processo político (...) De outra parte (...), importa referir a função decisiva exercida pelos direitos fundamentais num regime democrático como garantia das minorias contra eventuais desvios de poder praticados pela maioria no poder, salientando-se, portanto, ao lado da liberdade de participação, a efetiva garantia da liberdadeautonomia" (SARLET, Ingo Wolfgang. A eficácia dos direitos fundamentais: Uma teoria geral dos direitos fundamentais na perspectiva constitucional. 10 ed. Porto Alegre: Livraria do Advogado, 2010, p. 61).
} 
à justiça que logra a efetividade da jurisdição constitucional de proteção dos direitos fundamentais, em especial o do acesso à justiça.

Sob este vértice, ressalta-se que as noções de cidadania e democracia devem ser tratadas de maneira distinta, mas profundamente conectadas.

A noção de cidadania, tradicionalmente (conforme acepção liberal de democracia) consistindo no conjunto de direitos e obrigações legalmente conferidos aos indivíduos qualificados como cidadãos. Para tanto, CAVALCANTI (1999, p. 22) afirma que:

No pensamento liberal clássico, segundo o qual a cidadania tem origem no pacto social, quando se funda a nação e se organiza o Estado, pelo estabelecimento de uma constituição. Ser cidadão significa fazer parte de uma comunidade mais ampla, é identificar-se com uma nação particular e ter direitos - garantidos pelo Estado correspondente - e deveres para com a coletividade na qual se está inserido. (...) O cidadão é membro ativo de uma sociedade política independente.

Delimita-se, pois, noção estendida de cidadania, manifestada pela ideia de identidade política para com a res publica, não apenas relacionada ao estatuto legal. Para essa acepção estendida da cidadania, que parte da radicalização da democracia vislumbrada por Chantal Mouffe, o cidadão não se consubstancia tão somente um receptor passivo de direitos, mas, independente da noção particular de bem que possuam, unem-se em prol do reconhecimento de um conjunto de valores ético-políticos, articulando os ditames da res publica às identidades manifestadas (cidadania como princípio articulador).

Para MOUFFE (1996a, p. 21), a noção de cidadania:

É uma identidade política comum de pessoas, que podem estar empenhadas em muitos empreendimentos com finalidades diferentes e com diversas concepções de bem, mas que, na procura da sua satisfação e na execução das suas ações, aceitam submeter-se às regras prescritas pela res publica (...). É um princípio articulador, que afeta as diferentes posições de sujeito do agente social (...) ao mesmo tempo que permite uma pluralidade de compromissos e o respeito à liberdade individual.

Por outro lado, tradicionalmente, entende-se como democracia o sistema político em que os cidadãos participam das decisões públicas de maneira direta 
ou indireta, esta última através de representantes eleitos, tomando, no caso brasileiro, a forma de governo republicana. Exatamente por isso, parte do conceito de comunidade política em que os partícipes podem auxiliar, efetivamente, na consecução dos ideários ditos como relevantes.

Em sendo um conceito plural e passível de várias acepções, uma das quais se aborda no presente, ou seja, não esgotadas as suas possibilidades semânticas, pelo que permanece polissêmico e repleto de contextualizações possíveis, não esgota as observações a respeito de seu dever-ser, ou seja, a consideração da democracia como mandamento de governança do povo não olvida os desvios realísticos e seu mau funcionamento prático, sendo certo que, ao mesmo tempo em que se procura um linha mestra para funcionar como ponto de partida da análise da cidadania radical, igualmente se compreende como o que a democracia deve chegar a ser.

Anote-se, outrossim, a reflexão de CANOTILHO (2003, p. 289) a respeito da democracia enquanto processo dinâmico:

O princípio democrático não se compadece com uma compressão estática de democracia. Antes de mais, é um processo de continuidade transpessoal, irredutível a qualquer vinculação do processo político a determinadas pessoas. Por outro lado, a democracia é um processo dinâmico inerente a uma sociedade aberta e activa, oferecendo aos cidadãos a possibilidade de desenvolvimento integral e de liberdade de participação crítica no processo político em condições de igualdade econômica, política e social.

Com base nessas premissas, é que se estrutura o presente artigo em uma base dual que tem por objetivo, de um lado, pontuar as noções que abarcam o conceito de cidadania radical, para após e a partir, pensar o espaço político da jurisdição constitucional.

\section{CIDADANIA RADICAL}

A democracia radical, viabilizada e vivenciada por meio da cidadania radical, por seu turno, pretende conciliar a dimensão do conflito e do antagonismo da política, aceitando as consequências do inevitável dissenso e luta pela hegemonia através das instituições sociais, com vistas a restabelecer o espaço do político e efetivar o acesso à justiça do excluído - não raras vezes social, cultural e economicamente - que se vê distanciado da participação efetiva da tomada de decisões. 
A escolha por tal modelo teórico não se deu por acaso. Parte-se das noções fornecidas primeiramente por Chantal Mouffe $^{6}$ e, após, também por Ernesto Laclau ${ }^{7}$, que propugnam pela viabilização de um modelo de democracia que sirva como superação dos modelos propostos pela democracia liberal e comunitária, compreendendo o mesmo em sua dimensão utópica e, exatamente por isso, incompleta. Ou seja, ao afirmar a diferença e o ideário do político permeando todas as identidades do sujeito (cidadão, eleitor, pai de família, membro de associação, entre outros), e negando-se um espaço político unificado, chegase a importância da cidadania radical enquanto vetor da participação como emancipação e luta pacífica.

Para MOUFFE (2010b, p. 61):

Segundo esta visão liberal, a cidadania é a capacidade de cada pessoa formar, rever e realizar racionalmente a sua definição de bem. Entende-se que os cidadãos usam os seus direitos para promoverem os seus interesses próprios, com certas limitações impostas pela exigência de respeitarem os direitos dos outros.

Ainda, a esse respeito, KOZIKI in FONSECA (2004, p. 337):

Segundo Mouffe, contrariamente a essa perspectiva individualista do liberalismo, os comunitaristas propõem a renovação do chamado republicanismo cívico na política. Nessa perspectiva, existe uma forte ênfase na ideia de solidariedade e coesão social, com uma noção substantiva de bem comum, a qual seria anterior e independente dos interesses e desejos individuais. (...) Por isso mesmo, adota uma visão da comunidade como sendo constitutiva, ou seja, compondo a identificação do indivíduo, constituindo a identidade deste, em oposição à concepção liberal da comunidade instrumental.

Se o liberalismo se manifesta por meio dos ideais de defesa da liberdade individual e dos direitos individuais, da limitação do papel do Estado e do

${ }^{6}$ Cujo exponencial literário é imenso, possuindo como principais obras, que servirão como sustentáculo para a pesquisa a ser desenvolvida (o que por certo não a limita, apenas possibilitando referências iniciais de estudo): "The Democratic Paradox", "Dimensions of Radical Democracy: Pluralism, Citizenship, Community", "Deconstruction and Pragmatism", "The Political and the juridical", "Movilizar las pasiones democráticas", "The radical centre: A politics without adversary", Rawls: political philosophy without politics", "The return of the Political", "Wittgenstein: political theory and democracy".

7 Sobretudo na obra conjunta "Hegemony and Socialist Strategy: Towards a radical democratic politics". 
individualismo racionalista (além de sua manifestação econômica através do capitalismo), e se a tradição democrática se consubstancia pelo sufrágio universal, busca pela equidade e soberania popular, é imperioso que se reconheça que o relacionamento e articulação entre estas duas posturas não se dá sem embates no interior do espaço público.

Assim sendo, para se chegar à noção de cidadania radical não se pode olvidar que, se o liberalismo restringiu o espaço público de deliberação (reduzindo a democracia à luta das elites políticas), a procura por ações positivas do Estado mitigou essa diferenciação, sobretudo através do que se entende como revolução democrática. O que fica evidente é que a junção das duas tradições pressupõe esfera de conflituosidades e tensão entre a democracia enquanto sentimento de comunidade, unidade e equidade e o liberalismo com seu pluralismo, individualismo e liberdade. ${ }^{8}$

Ainda, no que tange ao tema, ainda explicita a supramencionada autora (2004, p. 335) que:

Tudo isso implica que, no tocante à cidadania, haverá sempre uma oposição entre o individualismo moral característico do liberalismo e a noção de comunidade, implícita no pensamento democrático. A construção de um conceito de cidadania, na ótica da democracia radical, implica uma noção de cidadão que, superando os limites de ambas as tradições, agregue em si a virtude de ambas. Na perspectiva da democracia liberal, é necessário conjugar o pluralismo, caro ao liberalismo, com o resgate dos valores de comunidade, virtude cívica e participação ativa na gestão das coisas da polis.

No mesmo sentido Claude Lefort, citado por Chantal Mouffe, fundamenta sua teoria da radicalização da democracia, na revolução democrática que se caracteriza pela separação da pessoa do rei ou soberano da ideia de unidade social, alterando-se a ordem (antes natural) simbólica dessa hierarquia (que pressupunha o soberano à frente), despersonificando o poder através do advento da democracia, passando o povo a ser tido como soberano. É exatamente por isso que o poder se torna um lugar vazio, e, a partir da concepção de que o mesmo não mais se funda em circunstâncias naturais e/ou divinas, tudo passa a ser questionado em si mesmo. (LEFORT, 1986, p. 303).

${ }^{8}$ KOZIKI in FONSECA (2004, p. 327-328). 
Partindo da dimensão de que tudo se encontra eivado por uma indeterminação radical e da formação de um nós que pressupõe a existência de um eles, encontra-se a relação amigo-inimigo que leva a um agonismo democrático ${ }^{9}$, objetivando encontrar na figura do outro um adversário cuja existência é legítima e deve ser respeitada.

Registre-se que a análise dessa indeterminação radical, enquanto significante vazio é de extrema relevância para a noção de cidadania radical que ora se desenvolve, haja vista que a partir dela se manifesta a dimensão utópica da democracia, sempre incompleta, sempre questionável, e sempre passível de transformação por vias pacíficas. Trata-se de uma abordagem desconstrucionista da democracia, visando encontrar as exclusões escondidas por detrás de uma hegemonia não democrática.

Tal análise se servirá do dimensionamento trazido por LEFORT (1986a, p. 303) para quem:

Não existe lei que possa ser fixada, cujos artigos não possam ser contestados, cujas fundações não possam ser suscetíveis de serem trazidas ao questionamento. Não existe representação de um centro e dos contornos da sociedade: a unidade não pode agora apagar a divisão social. A democracia inaugura a experiência do que não pode ser apreendido, uma incontrolável sociedade na qual a vontade do povo será chamada de soberana, é claro, mas suja identidade estará constantemente aberta ao questionamento, cuja identidade permanecerá sempre latente.

E o referido autor (1991b, p. 265) ainda explicita que:

A democracia moderna, como considerávamos, é o único regime a significar a separação do simbólico e do real com respeito á noção de um poder em que ninguém, príncipe ou pequeno grupo, seria capa de se apossar; sua virtude está em levar a sociedade à prova de sua instituição; lá onde se perfila um lugar vazio, não existe conjunção possível entre o poder, a lei e o saber, não existe enunciado possível de seu fundamento; o ser do social se furta, ou, melhor dizendo, se dá sob a forma de um questionamento interminável.

9 Contrariamente à ideia de antagonismo, em que o outro é inimigo e deve ser superado, comum à acepção liberal da democracia (CHUEIRI, Vera Karam de. Nas trilhas de Carl Schimit (ou nas Teias de Kafka): Soberania, Poder Constituinte e Democracia (Radical). In: FONSECA, Ricardo Marcelo. Repensando a Teoria do Estado. Belo Horizonte: Editora Fórum, 2004. p. 372-373). 
Sob este aspecto, DERRIDA (1997, pp. 10, 35-37, 42-43 e 62), analisando o "vínculo mútuo" que estabeleceu um "nós", apresentou a amizade como uma relação remota (ou como uma não-relação) entre agentes completamente diferenciados tanto um do outro como de si próprios, inaugurando uma "comunidade de amigos solidários" ou uma "comunidade sem comunidade, uma amizade sem a comunidade dos amigos de solidão" ou então, uma "comunidade anacoreta".

No ínterim da polarização entre moderno e pós-moderno ${ }^{10}$, desenvolveuse, por parte de Chantal Mouffe e Ernesto Laclau, projeto democrático que é, ao mesmo tempo, ambos. Neste ínterim, verifica-se que será de suma importância para o empreendimento científico a ser desenvolvido, a investigação acerca da negação de um espaço público unificado, sendo imperiosa a multiplicação de espaços políticos de participação e inclusão, visando, a partir da legitimação do conflito, o desenvolvimento de práticas de hegemonia democrática ${ }^{11}$.

\section{ACESSO À JUSTIÇA}

Sabido é que o acesso à justiça se consubstancia como direito e garantia fundamental, ou seja, que a todos se assegura o direito de dirigir-se à função judiciária e desta receber resposta no que tange a qualquer pretensão ${ }^{12}$, sua proteção deve ser sinônimo de uma democracia que implique e expresse paradigma de uma cidadania responsável pelo curso da história (CLÈVE, In: Revista de informação legislativa, v. 106, p. 98).

Se a ideia de cidadania radical perpassada pela democracia, incorpora as noções de agonismo e conflito na esfera de decisões políticas, é imperioso que se reconheça que o acesso à justiça, enquanto direito fundamental, igualmente precisa ser democratizado, com vistas a servir como sustentáculo de um Estado de direitos fundamentais.

Necessário se faz inverter a lógica do Estado com vistas a compatibilizar suas ações com os princípios fundamentais, radicalizando os instrumentos de

\footnotetext{
${ }^{10}$ Polarização esta iniciada por Jean François Lyoartd e Jürgen Habermas na década de 1980 segundo CRITINI (Jan-Jun/2007, p. 38-43).

${ }^{11}$ Até porque "cabe ao jurista ampliar, a partir da prática jurídica cotidiana, os espaços democráticos, libertários e igualitários do direito, sustentando a emergência de um direito emancipatório e protetor da dignidade do homem". (CLÈVE, Clèmerson Merlin. Para uma dogmática constitucional emancipatória. Belo Horizonte: Editora Fórum, 2012, p. 67).

12 "A lei não excluirá da apreciação do Poder Judiciário lesão ou ameaça a direito" (artigo $5^{\circ}$, inciso XXXV, Constituição da República Federativa do Brasil).
} 
democracia popular em prol da efetividade da jurisdição constitucional, que permita a viabilização da reserva de justiça propugnada pelo Constituinte ${ }^{13}$.

Acesso à justiça, como direito fundamental, significa a possibilidade concreta, passível de fruição por todos, desimpedida e efetiva, de acesso, por um lado, à prestação jurisdicional, e por outro, à ordem jurídica justa.

Registre-se, a propósito, o entendimento de WATANABE in TEIXEIRA (1996, p. 20) no que tange ao tema:

O princípio da inafastabilidade do controle jurisdicional, inscrito no inc. XXXV do art. $5^{\circ}$ da $\mathrm{CF}$, não assegura apenas o acesso formal aos órgãos judiciários, mas sim o acesso à Justiça que propicie a efetiva e tempestiva proteção contra qualquer forma de denegação da justiça e também o acesso à ordem jurídica justa. Cuida-se de um ideal que, certamente, está ainda muito distante de ser concretizado, e, pela falibilidade do ser humano, seguramente jamais atingiremos na sua inteireza. Mas a permanente manutenção desse ideal no coração dos operadores do direito é uma necessidade para que o ordenamento jurídico esteja em contínua evolução.

A própria noção de acesso denota a de inclusão, sendo certo que efetivar a garantia de acesso à justiça é combater todas as formas de exclusão que possam vir a separar o cidadão da prestação jurisdicional justa.

É o que orientam CAPPELLETTI e GARTY (2002, p. 08):

A expressão 'acesso à justiça' é reconhecidamente de difícil definição, mas serve para determinar duas finalidades básicas do sistema jurídico - o sistema pelo qual as pessoas podem reivindicar seus direitos e/ou resolver seus litígios sob os auspícios do estado. Primeiro, o sistema deve ser igualmente acessível a todos; segundo, ele deve produzir resultados que sejam individuais e socialmente justos.

Contudo, vários são os óbices encontrados na consecução dessa finalidade, tais como a morosidade da justiça, os altos custos do processo e a própria estrutura organizacional da jurisdição constitucional que, não raras vezes, excluem

\footnotetext{
${ }^{13}$ Transmutando a ideia de que o Estado, em sendo uma realidade instrumental, deve se voltar para a concretização de suas finalidades garantistas, Clèmerson Merlin Clève assevera que: "O Estado é uma realidade instrumental (...). Todos os poderes do Estado, ou melhor, todos os órgãos constitucionais têm por finalidade buscar a plena satisfação dos direitos fundamentais. Quando o estado se desvia disso ele está, do ponto de vista político, deslegitimando, e do ponto de vista jurídico, se desconstitucionalizando". (O controle de constitucionalidade e a eficácia dos direitos fundamentais, In: Jurisdição constitucional e direitos fundamentais - organizado por José Aderico Leite Sampaio, 2003, p. 388).
} 
as minorias da participação efetiva da democracia repartida sob a égide da função judiciária.

CAMARGO (2009, p. 47) leciona que:

Alguns dos elementos obstaculizadores ou complicadores do acesso à justiça podem ser relacionados: os altos custos, a morosidade relativa a um processo, a falta de uma defensoria pública completa, procedimentos complicados, o formalismo do próprio ambiente forense e dos operadores do direito, a figura opressora dos promotores, juízes, advogados, delegados e, em última instância, a falta de consciência dos direitos (cidadania).

Excluídos, os cidadãos, já desconfiados no que diz respeito a atuação da função legislativa e executiva, em crise de representatividade, se distanciam (ou sequer se aproximam?) também da função judiciária.

Nas palavras de ALARCÓN (2005, p. 39-40):

No Brasil registra-se um fenômeno singular. De um lado, grandes segmentos da população se encontram distantes do judiciário, pelo outro, um congestionamento maiúsculo impede a agilidade da prestação jurisdicional e produz uma melancólica lentidão. Tão urgente é o problema que se requerem estratégias definidas, audaciosas e firmes, de modo a projetar uma realidade onde o povo e o Judiciário sejam vizinhos na cooperação e na procura e promoção de fórmulas alternativas de solução de conflitos que cumpram o escopo da pacificação social.

A vertente filosófica da cidadania radical possui o condão de utilizar as noções trazidas pela democracia radical, para viabilizar o redimensionamento do espaço público de participação cidadã, em prol daqueles que não conseguem obter prestação jurisdicional satisfatória ou nem chegam a busca-la, ou seja, concretizando o direito fundamental ao acesso à justiça no ínterim da jurisdição constitucional com vistas à efetivação dos ditames democráticos.

\section{REPENSANDO O ESPAÇO DO POLÍTICO ATRAVÉS DA JURISDIÇÃO CONSTITUCIONAL}

A delimitação do foco de análise na inclusão na jurisdição constitucional não se deu de forma impensada, cabendo à referida expressão jurisdicional a proteção da maioria permanente, caracterizada pelo Poder Constituinte, contra 
as maiorias eventuais, consubstanciadas pelas legislaturas e governos periódicos (CLÈVE, 2012a, p. 25).

Desse modo, sopesada não a mitigação da atuação política pela função judiciária, mas sim o controle de sua legitimidade, esta se evidencia como espaço de luta ideal ao acesso à justiça daqueles que necessitam de inclusão $0^{14}$, bem como arena para disputas discursivas pacíficas e de legitimação do conflito a partir da concepção radicalizada da cidadania.

A esse respeito, CRITINI (Jan-Jun/2007, p. 41) ressalta que “(...) Uma interpretação democrática radical enfatizará as numerosas relações sociais onde existem relações de dominação para desafiá-las, com a aplicação dos princípios da liberdade e igualdade".

Anote-se que a preocupação da democracia radical não deve ser a de descobrir como eliminar o poder, mas sim como construir formas de poder compatíveis com o espírito democrático. Por meio da lógica da equivalência, se incorpora as diferentes demandas no discurso libertário, ou seja, os diferentes projetos políticos lutam para articular um grande número de significantes ao redor de si. O direito, dessa maneira, ganha contornos de estabilizador das tensões existentes na política, haja vista que se é a diversidade o vetor de transformação social, sem inclusão, as diferenças se degeneram.

Se para a democracia radical é possível se reconhecer que os cidadãos, com diversas concepções particulares de bem, aceitam submeter-se aos valores ético-políticos da res publica, e se considerarmos que em uma democracia liberal a supramencionada res publica se constitui pelos princípios da igualdade e liberdade para todos (princípios estes em tensão constante), uma interpretação democrática radical da cidadania enfatizará as numerosas relações sociais que transmutam relações de domínio, que precisarão ser questionadas com vistas a efetivar os princípios da liberdade e igualdade, imprescindíveis como objetivos e, ao mesmo tempo, pressupostos, do acesso à justiça.

\footnotetext{
14 "Com a garantia da observância das normas constitucionais conexionam-se relevantíssimas questões político-constitucionais como: (1) defesa das minorias perante a omnipotência da maioria parlamento-governo; (2) primazia hierárquico-normativo da Constituição e do legislador constituinte perante a omnipotência da maioria parlamento-governo; (3) primazia do dogma tradicional da presunção de constitucionalidade dos actos legislativos; (4) legitimidade do desenvolvimento do próprio direito constitucional através da interpretação dada ás normas da Constituição pelos juízes constitucionais. Perante esse cruzamento de questões político-constitucionais, o Tribunal Constitucional poderá desempenhar o papel de regulador e determinador da própria identidade cultural da República (Ebsen) e de controlador do legislador mastodonte e da administração leviathan (Cappelletti)". (CANOTILHO, JJ. Gomes. Direito Constitucional e Teoria da Constituição. 7 ed. Coimbra: Almedina, 2003, p. 681-682).
} 
Além disso, levará grupos diferentes, que lutam pela extensão da radicalização democrática, a perceberem que carregam entre si interesses comuns e que a escolha de suas condutas deverá ser permeada por determinadas regras de conduta, conduzindo a uma identidade política comum de cidadãos radicais democratas. Ou seja, a criação de identidades políticas como cidadãos radicais democratas depende então de uma forma de identificação coletiva entre as exigências democráticas de uma diversidade de movimentos: mulheres, trabalhadores, negros, homossexuais, ecologistas, bem como dos chamados "movimentos sociais novos".

Quanto a esse mister, MOUFFE e LACLAU (1985, p. 32), na tentativa de analisar as conceituações tradicionais de conflitos sociais asseveram que:

O que caracteriza os novos movimentos sociais, então, é que, através deles, rompeu-se a unidade destes três aspectos de paradigma. Por um lado, tornase cada vez mais impossível identificar o grupo, concebido como referente, com um sistema ordenado e coerente de 'posições de sujeito'. Vejamos o exemplo do trabalhador ou trabalhadora. Será que há alguma relação estável entre sua posição nas relações de produção e sua posição como consumidor(a), habitante de uma área específica, participante de um sistema político? Evidentemente, a relação entre estas diferentes posições está longe de ser óbvia e permanente; ao contrário, ela constitui o resultado de construções políticas complexas, baseadas na totalidade das relações sociais, e que não podem decorrer unilateralmente das relações de produção. Os novos movimentos sociais têm sido caracterizados por uma crescente politização da vida social (...), mas também é precisamente esse ponto que fez ruir a visão do político como um espaço fechado e homogêneo.

Esta é uma concepção de cidadania que, através de uma identificação comum com uma interpretação democrática radical dos princípios da liberdade e da igualdade, visa construir um "nós”, em sucessão de equivalências entre as suas exigências e expectativas, de forma a articulá-las pelo princípio da equivalência democrática.

Logra a demonstração da maneira com a qual se permeia e expande o político, através de uma ressignificação da identidade coletiva e agregação dos movimentos sociais como espaços de luta e reinvindicação, possuindo como objeto de atuação e plano de fundo a atividade política desempenhada pela jurisdição constitucional e seu protagonismo, com vistas a analisar a influência (ou a fragilidade desta) de tal participação neste ínterim, ou seja, como se dá e 
como pode se dar a atuação dos movimentos sociais , pautados pela radicalização da democracia, como forma de participação popular na jurisdição constitucional. Aliás, é extremamente relevante para o tema que se propõe acerca do redimensionamento do espaço político no que tange à jurisdição constitucional. Se repensar e multiplicar as esferas passíveis de democratização do discurso e inclusão se consubstancia em elemento legitimador da própria jurisdição constitucional e da atividade política não raras vezes por ela desempenhada, logo, efetivar o acesso do cidadão mobilizado é garantir a aplicação da reserva de justiça propugnada pelo Constituinte, enquanto direito fundamental esperado de um Estado que almeja ser democrático.

Para MOUFFE e LACLAU (1985, p. 34):

A transição para esta nova forma de política implica numa mudança decisiva: a transformação do papel do imaginário político. Assim denominamos o conjunto de significados que, no âmbito de um determinado complexo ideológico discursivo, operem como um horizonte, ou seja, como o momento de totalização equivalente de várias confrontações e lutas parciais. Este horizonte está sempre presente, mas seu papel na constituição dos significados políticos pode variar consideravelmente. Podemos indicar duas situações extremas. Na primeira, há uma desproporção radical entre a situação efetiva de denominação e a possibilidade de combater a força dominante e, a este respeito, travar uma batalha eficaz de posição contra a mesma. Neste caso, o conflito é exclusivamente concebido e vivenciado num nível imaginário; a função do horizonte não é permitir a totalização de uma massa de confrontações parciais mas, ao contrário, constituir o significado primário das mesmas. Mas pela própria razão desse horizonte possuir essa função constitutiva primária, o social somente pode ser vivenciado e concebido como uma totalidade. No segundo caso, em contraste, cada luta parcial atinge o objetivo de se constituir como uma batalha de posições e, assim sendo, retira de si mesma, de seu caráter único e diferencial, o mundo de significados que permitem a constituição de uma identidade social ou política: O momento de totalização é então puramente um horizonte e seu relacionamento com os antagonismos concretos torna-se instável e assume uma certa exterioridade.

STRECK (2004, p. 844) assevera, ao contextualizar o tempo de promulgação de nossa Constituição Federal e sua efetividade (sobremaneira atual, passados mais de vinte anos de promulgação) que:

É nesse exato contexto que, considerando a Constituição não somente como o/um documento para organizar o Estado, mas, sim, a própria explicitação do contrato social e o espaço de mediação ético-política da sociedade, ou, como 
diz Bonavides, 'é a expressão do consenso social sobre os valores básico, tornando-se o alfa e o ômega da ordem jurídica, fazendo de seus princípios, estampados naqueles valores, o critério mediante o qual se mensuram todos os conteúdos normativos do sistema', é necessário ter claro que o cumprimento do texto constitucional é condição de possibilidade para a implantação das promessas da modernidade, em um país em que a modernidade é (ainda) tardia e arcaica. Para que se cumpra a Constituição necessitamos, primeiro, superar essa paradigma normativista, próprio de um modelo de Direito liberal, individualista, hegemônico no plano das práticas judiciárias, no qual os próprios mecanismos para viabilizar os direitos sociais e fundamentais, passados treze anos de promulgação da Constituição, têm permanecido ineficazes.

De igual modo, os movimentos sociais, como expressão da cidadania radical, identidade coletiva e emancipatória, devem empregar, a partir de seu direito fundamental ao acesso à justiça, instrumentos jurídicos capazes de plasmar seus interesses no jogo de discurso democrático (otimizando os já existentes e desmascarando os códigos fechados da linguagem do poder e dominação), mediante práticas hegemônicas democráticas passíveis de implementar, por vias pacíficas, suas prerrogativas.

Rompe-se com a dominação legítima que atua por meio de um Estado que provoca consenso das partes dominadas, como ressalta POULANTZAS (1977, P. 13-14):

Com efeito, por um lado, as classes dominantes não podem dominar as classes exploradas, por meio do Estado, através do simples emprego da violência, por força física. Esta violência deve sempre se apresentar como legítima, por uma atuação, por meio do Estado, da ideologia dominante capa de provocar um certo consenso da parte de algumas classes e frações dominadas. Por outro lado, o próprio Estado tem, com relação ao bloco no poder, um papel de organização, unificando-o e instaurando seu interesse político geral face às lutas das classes dominadas: o papel de unificação-representação do Estado com relação às próprias classes dominantes, que apela diretamente para a ideologia dominante.

Nesse influxo a intervenção de LEAL (2003, p. 851) a esse respeito, para quem:

A capacidade de mobilização e organização social propiciou um processo de conscientização política gradual e em desenvolvimento dos novos 
movimentos sociais, já que necessitam decifrar os códigos fechados da linguagem do poder e da administração para os fins de buscar a implementação e promoção de suas prerrogativas garantidas pelos sistemas jurídicos operantes. (...) É igualmente frágil a tese de que um excesso de participação da sociedade acarretaria desgaste às formas clássicas de representação política da democracia moderna, isto porque não são incompatíveis com os novos sujeitos sociais que são os grupos mobilizados de determinados setores da comunidade. Se é verdade que tais movimentos apresentam perfis organizacionais próprios, inserção específica da tessitura social e articulações particulares com o arcabouço do poder existente, não é menos real de que eles também necessitam da esfera pública a institucional do debate que lhes dizem respeito (por exemplo, dialogando com o Estado para obter dele demandas que os afligem.

A jurisdição constitucional precisa ser tomada como realmente é e deve ser: instrumento concreto com vistas a conservar os ditames constitucionais (enquanto pré-compromissos ${ }^{15}$ ) de satisfação das necessidades e expectativas do povo soberano. Imperioso que se reconheça a jurisdição constitucional como arena ideal de luta, transformação e emancipação, sendo a participação popular (através da cidadania radical que propõe este trabalho) imprescindível ${ }^{16}$ na construção da radical democracia que compatibilize as diversas concepções particulares de bem com a identificação com a res publica.

\footnotetext{
${ }^{15}$ Como salienta ELSER, os pré compromissos constitucionais são estratégias de auto capacitação, extraídas dos pré compromissos individuais (como uma pessoa com dificuldade em acordar que posicional seu despertador longe de si), por meio dos quais um indivíduo ou um povo, em um momento de lucidez (constitucional), afasta a possibilidade de adotar decisões míopes a que estaria tendencialmente sujeito em momentos de debilidade, logrando, dessa forma, afastar tentações ou fraquezas e atingir os seus verdadeiros interesses. (ELSER, Jon. Ulisses and the Sirens: studies in rationality and irracionality. Great Britain: Cambridge University Press, 1979).

${ }^{16}$ Até porque, a soberania popular, que deve permear a atuação de todas as parcelas do poder estatal (incluindo a judiciária) é o que legitima a própria atuação da jurisdição constitucional, conforme leciona Sérgio Fernando Moro: "A Constituição é deve ser considerada pelos juízes como a lei fundamental; e, como a interpretação das leis é a função especial dos tribunais judiciários, a eles pertence determinar o sentido da Constituição, assim como de todos os outros atos do corpo legislativo. Se entre estas leis se encontrarem algumas contraditórias, deve-se preferir aquela cuja observância é um dever mais sagrado; que 'o mesmo que dizer que a Constituição deve ser preferida a um simples estatuto; ou a intenção do povo à dos seus agentes. Mas não se segue daqui que o Poder Judiciário seja superior ao Legislativo: segue-se, sim, que o poder do povo é superior a ambos e que, quando a vontade do corpo legislativo, declarada nos seus estatutos, está em oposição com a do povo, declarada na Constituição, é a esta última que os juízes devem obedecer; por outras palavras, que as suas decisões devem conformar-se antes com as leis fundamentais do que com aquelas que não o são”. (MORO, Sérgio Fernando. Jurisdição constitucional como democracia. São Paulo: Revista dos Tribunais, 2004, p. 128-129).
} 


\section{CONSIDERAÇÕES FINAIS}

É preciso que se reconheça que a cidadania radical não pode se esgotar em um estatuto político garantidor de direitos negativos quando confrontados com o Estado, e tampouco pode o bem comum mitigar a esfera de direitos individuais do cidadão, sendo imperioso que, dimensionados em uma sociedade concreta, se identifiquem com a res publica independentemente da noção de bem comum que possuam enquanto cidadãos.

Não se trata, meramente, de compreender a cidadania como uma identidade em meio a várias (como sucede no liberalismo), e nem se suplantála como sobreposta às outras (como no comunitarismo), mas sim de observá-la enquanto princípio articulador que permite uma pluralidade de compromissos com respeito à liberdade individual, sob o risco de persistir na democracia meramente como signo simbólico ${ }^{17}$ e repetidor de relações sociais excludentes e conflitos ilegítimos.

Como ressalta MAGALHÃES (2009, p. 305):

O risco, então, é de uma constitucionalização meramente simbólica. E, como se sabe, os símbolos revelam-se tanto capazes de iluminar quanto de ocultar: a constituição simbólica pode adquirir um caráter de idealidade, de horizonte para as expectativas sociais se projetarem e se construírem no tempo; mas pode, também, assumir contornos de um mecanismo de ocultação, de invisibilização, daquilo que a sociedade recusa-se a observar em si mesma.

Compreendida dessa maneira, e redimensionado conceito de cidadania, esta passa a permear todas as esferas de atuação do agente, repensando-se o espaço do político, antes restrito aos fóruns oficiais de deliberação, distantes da vida privada do cidadão que pouco intervém na condução da sociedade em que vive. Vale dizer que, se não intervém e participa, aos poucos desconhece as funcionalidades do próprio Estado, degenerando-se, também, o conceito de espaço público.

Para SLATER in ALVAREZ (2000, p. 512):

\footnotetext{
17 "O risco, então, é de uma constitucionalização meramente simbólica. E, como se sabe, os símbolos revelam-se tanto capazes de iluminar quanto de ocultar: a constituição simbólica pode adquirir um caráter de idealidade, de horizonte para as expectativas sociais se projetarem e se construírem no tempo; mas pode, também, assumir contornos de um mecanismo de ocultação, de invisibilização, daquilo que a sociedade recusa-se a observar em si mesma". (MAGALHÃES, Juliana Neuenschawander. Constituição e Diferença. In: SAMENTO, Daniel (Coord.). Filosofia e Teoria Constitucional Contemporânea. Rio de Janeiro: Editora Lumen Juris,, 2009, p. 305).
} 
Mouffe, por exemplo, num ponto de vista que se liga ao trabalho anterior de Lefort, escreve que para ela 'o político' se relaciona com a dimensão antagonista que é inerente a toda sociedade humana - um antagonismo que pode assumir diferentes formas a ser localizado em diversas relações sociais. Em contraste, a 'política' pode ser tomada como se referindo ao conjunto de práticas, discursos e instituições que buscam estabelecer uma certa ordem e organizar a vida social em condições que estão sempre potencialmente sujeitas ao conflito precisamente porque são afetadas pela dimensão 'do político'.

Ou seja, se o antagonismo é inerente à toda a sociedade humana (em sua variedade de inter-relações), a política se consubstancia em um conjunto de práticas que organiza a vida social que está sempre em potencial conflito (o outro passa de inimigo para opositor em uma rena de conflito institucionalizada). E exatamente essa prática, relacionando o direito fundamental ao acesso à justiça e os ditames da democracia radical que objetiva a construção de uma dogmática constitucional emancipatória já que, nos dizeres de CLÈVE (2012a, p. 36):

Não basta o discurso-denúncia. Não basta o discurso antropologicamente simpático ou amigo (amigo das classes populares, amigos dos pobres, amigo dos humanismo, amigo das esquerdas), como afirma Canotilho. Mais do que isso, importa, para o jurista participante, sujar as mãos com a lama impregnante da prática jurídica, oferecendo, no campo da dogmática, novas soluções, novas fórmulas, novas interpretações, novas construções conceituais. Este é o grande desafio contemporâneo. Invadir um espaço tomado, muitas vezes, por forças conservadores, lutando ombro a ombro, no território onde elas imperar, para, com a reconstrução da dogmática, alijá-las de suas posições confortavelmente desfrutadas.

Assim sendo, a cidadania radical, inspirada na vertente filosófica propugnada por Chantal Mouffe, como vetor de influência e transformação da inefetividade do acesso à justiça no ínterim da jurisdição constitucional, propugna por uma "revolução democrática" e pauta-se pelas noções de agonismo democrático e acepção utópica da democracia, em prol da negação de um espaço público unificado. Nesse ínterim, a partir da necessidade de multiplicação dos espaços de participação e inclusão, e considerando o protagonismo da atuação judicial que deve empreender esforços para a consecução de direitos e garantias fundamentais, tem-se na jurisdição constitucional arena de luta pacífica de acesso em prol da reserva de justiça propugnada pelo Constituinte. 


\section{REFERÊNCIAS}

AGAMBEN, Giorgio. Homo Sacer a Vida Nua. Trad. Henrique Burigo. Belo Horizonte: Editora UFMG, 2002.

BONAVIDES, Paulo. Do Estado Liberal ao Estado Social. 4 ed. Rio de Janeiro: Forense, 1980.

BONAVIDES, Paulo. Do País Constitucional ao País Neocolonial: a derrubada da Constituição e a recolonização pelo golpe de Estado institucional. 2 ed. São Paulo: Malheiros, 2001.

CAMARGO, Daniel Marques de. Jurisdição crítica e direitos fundamentais. Porto Alegre: Nuria Fabris Editora, 2009.

CANOTILHO, J.J. Gomes. Direito Constitucional. 5 ed. Coimbra: Livraria Almedina, 1992.

CANOTILHO, JJ. Gomes. Direito Constitucional e Teoria da Constituição. 7 ed. Coimbra: Almedina, 2003.

CLÈVE, Clèmerson Merlin. Para uma dogmática constitucional emancipatória. Belo Horizonte: Editora Fórum, 2012.

CLÈVE, Clèmerson Merlin (Coord.). Constituição, Democracia e Justiça: Aportes para um constitucionalismo igualitário. Belo Horizonte: Editora Fórum, 2011.

CLÈVE, Clèmerson Merlin. Soluções Práticas de Direito. São Paulo, Revista dos Tribunais, 2012.

CLÈVE, Clèmerson Merlin. O Direito e os Direitos: elementos para uma crítica do Direito Contemporâneo. 3. Ed. Belo Horizonte: Editora Fórum, 2011.

CLÈVE, Clèmerson Merlin (Org.); SARLET, Ingo Wolfagang (Org.); PAGLIARINI, Alexandre Coutinho (Org.); Direitos Humanos e Democracia. Rio de Janeiro, Forense, 2007. 
CLÈVE, Clèmerson Merlin. Temas de Direito Constitucional (e de Teoria do Direito). São Paulo: Acadêmica, 1993.

COSTA, Pietro. Soberania, representação e democracia: Ensaio sobre a história do Pensamento Jurídico. Curitiba: Juruá, 2010.

DERRIDA. Acts of Literature. New York: Routledge, 1992.

DERRIDA. Force de Loi: le "foudement mystique de l'autorite".

Desconstruction and the possibility of justice. Cardozo Law Review, v 11., n. 5-6, july/aug. 1990.

DERRIDA, Politics of Friendship, Trad. por George Colllins. Londres: Verso, 1997.

FARIA, José Eduardo (Org.). Direitos humanos, direitos sociais e justiça. São Paulo: Editora Malheiros, 1998

FONSECA, Ricardo Marcelo (Org.). Repensando a Teoria do Estado. Belo Horizonte: Editora Fórum, 2004.

GARGARELLA, Roberto. Democracia Deliberativa e o papel dos juízes diante dos direitos sociais. Revista de direito do Estado. Rio de janeiro, ano 3, número 10, 3-23, abril/junho 2008.

HABERMAS, Jürgen. Direito e Democracia: entre facticidade e validade. Tradução de Flávio Beno Siebeneichler. Tempo Brasileiro: Rio de Janeiro, 1997, v. 1, 2.

KOZICKI, Katya. Conflito e Estabilização: comprometendo radicalmente a aplicação do direito com a democracia nas sociedades contemporâneas. Tese (Doutorado). Florianópolis, UFSC, 2000.

LACLAU, Ernesto; MOUFFE, C. Hegemony and Socialist Strategy:

Towards a radical democratic politics. London: Verso, 1985.

LEFORT, Claude. Democracy and Political Theory. Minneapolis:

University of Minneapolis Press, 1988. 
LEFORT, Claude. As formas da História: Ensaios de Antropologia Política. São Paulo: Brasiliense, 1981.

LEFORT, Claude. A invenção democrática: Os limites do totalitarismo. 2 ed. São Paulo: Editora Brasiliense, 1981.

LEFORT, Claude. Political Forms of Modern Society: bureaucracy, democracy, totalitarianism. Cambridge: MIT Press, 1986.

LEFORT, Claude. Pensando o Político. São Paulo: Terra e Paz, 1991.

MACEDO, Ubiratan Borges de. Democracia e Direitos Humanos. 1.ed. Londrina: Edições Humanidades, 2003.

MOFFE, Chantal. The Democratic Paradox. London: Verso, 2000.

MOUFFE, Chantal. Dimensions of Radical Democracy: Pluralism, Citizenship, Community. London: Verso, 1992.

MOUFFE, Chantal. Desconstruction and Pragmatism. London: Routledge, 1997.

MOUFFE, Chantal. O regresso do Político. São Paulo: Gradiva, 2010.

MOUFFE, Chantal. Movilizar las pasiones democráticas. Semanário de Política y Cultura, México, n. 190, 0. 21-27, sep. 1996.

MOUFFE, Chantal. Rawls: political philosophy without politics. Philosophy and Social Criticism, London, v. 13, n. 2, p. 105-123, 1987.

NETO, Cláudio Pereira de Souza. Teoria Constitucional e Democracia Deliberativa. 1.ed. Rio de Janeiro: Editora Renovar, 2006.

RAWLS, John. Uma teoria da justiça. 2. Tiragem. São Paulo: Martins Fontes, 2002.

RAWLS, John. "Commonweal Interview with John Rawls", in:

Commonweal, v. 125, n. 16 (September 25, 1998): 12-17. 
RAWLS, John. O liberalismo político. 2. ed. São Paulo: Ática, 1993.

SCHIMITT, Carl. The Concept of the Political. Chicago: The University of Chicago Press, 1996.

SANDEL, Michael. Justiça. O que é fazer a coisa certa. Rio de Janeiro: Civilização Brasileira Editora, 2012.

SARLET, Ingo Wolfgang. A eficácia dos direitos fundamentais: Uma teoria geral dos direitos fundamentais na perspectiva constitucional. 10 ed. Porto Alegre: Livraria do Advogado, 2010.

SARMENTO, Daniel (Coord.). Filosofia e Teoria Constitucional Contemporânea. Rio de Janeiro: Editora Lumen Juris,, 2009

SMITH, Anna. Laclau and Mouffe. The radical democratic imaginary. London: Routledge, 1998.

STRECK, Lênio Luiz. Hermenêutica Jurídica e(m) crise: Uma exploração hermenêutica da construção do Direito. Porto Alegre: Livraria do Advogado Editora, 2001.

STRECK, Lênio Luiz; MORAIS, José Luis Bolzan. Ciência Política e Teoria Geral do Estado. Porto Alegre: Livraria do Advogado, 2000.

TOCQUEVILLE, Alexis de. A democracia na América. São Paulo: Martins Fontes, 2001.

Artigo recebido em: 25/03/2015 Aprovado para publicação em: 23/04/2015

Como citar: PAIVA, Ana Paula de Oliveira Mazoni Vanzela. FACHIN, Melina Giradi. Democracia radical e acesso à justiça: repensando o espaço do político na jurisdição constitucional. Revista do Direito Público. Londrina, v.10, n.1, p.189-210, jan./abr.2015. DOI: 10.5433/1980-511X.2015v10n1p189. 